Sains Malaysiana 47(3)(2018): 517-522

http://dx.doi.org/10.17576/jsm-2018-4703-11

\title{
Kajian Dok Molekul Mengenai Interaksi antara RNA-Bergantung RNA Polimerase Virus Denggi dan Analog Nukleosida
}

(Molecular Docking Study of the Interactions between Dengue Virus RNA-Dependent-RNA Polymerase and Nucleoside Analogues)

\author{
Nor NADIRAH ABDUllaH, Kamal RUllaH, LAM KOK WAI \& MALINA JASAMAI*
}

\begin{abstract}
ABSTRAK
Enzim RNA-bergantung RNA polimerase adalah sasaran dadah yang menarik untuk mengubati jangkitan denggi. Analog nukleosida menyerupai substrat asal enzim polimerase. Ia bertindak sebagai perencat atau substrat kepada enzim ini lalu menyebabkan penamatan pramatang bebenang DNA/RNA atau penghasilan DNA/RNA yang rosak. Ini akan menghentikan proses replikasi virus. Kajian dok molekul untuk mengenal pasti interaksi molekular antara enzim dan ligannya telah dilakukan berdasarkan maklumat yang diperoleh berkenaan struktur kristal domain RdRp. Tapak pengikat-ligan domain RdRp yang terdiri daripada sisa asid amino Asn492, Asn405, Lys401, Thr605 dan Gly601 telah dikenal pasti setelah pengedokan analog nukleosida yang boleh didapati secara komersial dijalankan. Pengedokan analog nukleosida yang menyerupai substrat asal RdRp ke dalam tapak pengikat menunjukkan mod pengikat-ligan dengan ikatan hidrogen, aromatik- $\pi$ dan interaksi cas adalah interaksi utama yang terlibat. Kajian ini juga memberi maklumat berkenaan farmakofor analog nukleosida yang boleh digunakan dalam reka-bentuk dadah berasaskan struktur terhadap sasaran penting ini.
\end{abstract}

Kata kunci: Analog nukleosida; dok molekul; enzim RdRp; tapak pengikat-ligan; virus denggi

\section{ABSTRACT}

RNA-dependent RNA polymerase (RdRp) enzyme is an attractive drug target to treat dengue infection. Nucleoside analogues are mimics of natural substrates for polymerase enzymes. They act as inhibitors or substrates for these enzymes resulted in the premature termination of the DNA/RNA strands or formation of faulty DNA/RNA strands. This will halt the virus replication process. Based on the published crystal structure of RdRp domain, docking study to identify molecular interactions between the enzyme and its ligands were performed. Docking of the commercially available nucleoside analogues identified the ligand-binding pocket of the RdRp domain encompasses of Asn492, Asn405, Lys401, Thr605 and Gly601 amino acid residues. Docking of the nucleoside analogues, mimics of the natural substrate for RdRp into this pocket showed the ligand-binding mode, in which hydrogen bonding, $\pi$-aromatic and charge interactions are the main forces involved. This study also showed the pharmacophore of the nucleoside analogues which will be useful in structure-based drug design against this important target.

Keywords: Dengue virus; ligand-binding pocket; molecular docking; nucleoside analogues; RdRp enzyme

\section{PENGENALAN}

Virus denggi diklasifikasi sebagai famili Flaviviridae yang mempunyai tiga genera iaitu Hepacivirus, Pestivirus dan Flavivirus. Flavivirus muncul sebagai patogen penting yang mengundang kebimbangan terhadap kesihatan awam dunia disebabkan oleh wabak penyakit yang dibawa olehnya (Malet et al. 2008). Berikut adalah antara patogen tersebut; Virus Nil Barat (WNV), Virus Ensefalitis Jepun (JEV), Virus Demam Kuning (YFV) dan Virus Denggi (DENV) (Chen et al. 2010). Selepas menjangkiti perumah, RNA genom virus akan bertindak sebagai RNA utusan (mRNA) yang terlibat dalam sintesis protein berstruktur dan tidak berstruktur. Protein tidak berstruktur (NS1-NS5) yang terhasil terlibat dalam proses replikasi virus. Replikasi RNA melibatkan sintesis benang tolak pelengkap yang digunakan sebagai templat bagi pengeluaran benang tambah. Enzim RNA- bergantung RNA-polimerase ( $\mathrm{RdRp})$ adalah enzim penting dalam proses replikasi ini (Tan et al. 1996).

RdRp DENV terletak di kawasan terminal-C NS5 dan mempunyai tiga subdomain yang dinamakan sebagai tapak tangan, jari dan ibu jari (Malet et al. 2008). Subdomain tapak tangan mengandungi tapak aktif dan terdiri daripada dua benang- $\beta$ tidak selari yang dikelilingi oleh lapan helix- $\alpha$. Dua motif utama iaitu motif A (Asp533) dan motif C (Asp663) memainkan peranan penting dalam mekanisme pemangkin oleh enzim ini (Steitz 1998). Subdomain jari pula terdiri daripada dua hujung jari dan teras. Salah satu daripada hujung jari mempunyai motif F yang menyediakan tapak pengikat nukleotida trifosfat (NTP) dalam replikasi RNA (Bruenn 2003). Motif E yang berperanan sebagai perangsang sediaan NTP terkandung di dalam subdomain ibu jari (Adachi et al. 2002). 
RdRp DENV merupakan sasaran unik dalam pembangunan agen antiviral kerana aktiviti polimerase ini penting untuk proses replikasi virus dan enzim ini tidak wujud dalam sel perumah (Cerruti \& Casas-Mollano 2006). Nukleosida trifosfat adalah substrat kepada enzim ini dan sesuai untuk dijadikan sebagai sebatian pemula dalam kajian penemuan dan pembangunan dadah. Analog nukleosida adalah antara sebatian yang dibangunkan sebagai perencat enzim polimerase dan digunakan dengan meluas sebagai agen antiviral untuk pelbagai jangkitan virus seperti virus herpes simpleks (HSV), virus kurang daya tahan imun manusia (HIV) dan hepatitis B virus (HBV). Analog nukleosida tidak aktif dalam bentuk sedia ada dan perlu diaktifkan kepada analog nukleosida trifosfat oleh enzim kinase perumah atau virus dalam proses fosforilasi (De Clercq \& Neyts 2009). Walau bagaimanapun, maklumat berkenaan mod mengikat antara ligan ini dengan RdRp DENV adalah terhad, justeru melambatkan kajian pengoptimuman perencat sedia ada atau untuk mereka bentuk perencat yang lebih poten dengan menggunakan kaedah reka bentuk dadah berasaskan-struktur.

Kertas ini membincangkan keputusan kajian dok molekul antara domain RdRp DENV dan ligannya berdasarkan struktur kristal RdRp. Keputusan kajian menunjukkan mod ikatan ligan pada tapak pengikat. Selain daripada itu, maklumat penting berkenaan farmakofor perencat RdRp DENV juga dikenal pasti dan ini amat berguna dalam kajian reka-bentuk perencat polimerase yang baharu.

\section{BAHAN DAN KAEDAH}

Sebanyak 18 analog nukleosida komersial digunakan dalam kajian ini (Rajah 1). Struktur 3D ligan dibina dengan menggunakan perisian ChemBio 3D dalam progam

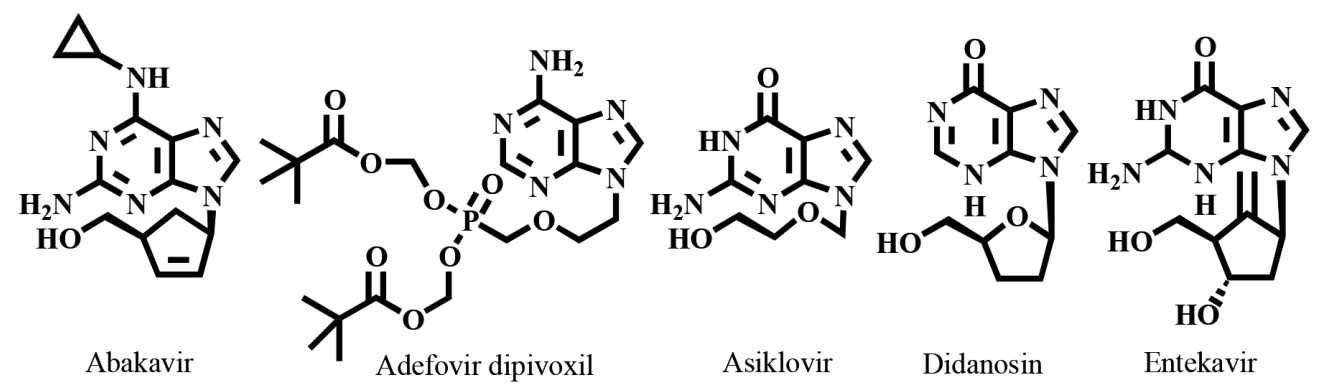

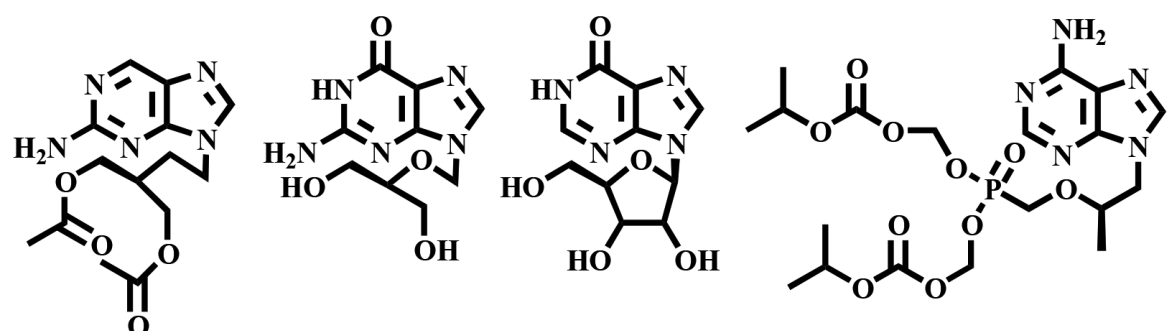<smiles>CC(C)[C@H](N)C(=O)OCCOc1nccn2cncc12</smiles>

Valasiklovir

Gansiklovir

Inosin

Tenofovir<smiles>Nc1nc(=O)n2cc(F)c(F)nc2c1COO</smiles>

Emtrisitabin<smiles></smiles>

Lamivudin<smiles></smiles>

Ribavirin<smiles></smiles>

Stavudin<smiles>NC1C=CN(CC(CO)OCP(=O)(O)O)C(=O)N1</smiles><smiles>Cc1cn(C2CC(O)C(CO)O2)c(=O)[nH]c1=O</smiles><smiles></smiles><smiles>Cc1oc2ccc(NS(=O)(=O)c3ccc(I)cc3)cc2c1C(=O)O</smiles>

NITD 107

RAJAH 1. Struktur kimia analog nukleosida dan perencat asal enzim 
pemodelan molekul Accelrys Discovery Studio 3.1. Atom hidrogen ligan ditambah dan cas atom ligan diberi dengan menggunakan potensi CHARMm. Ligan ini kemudian dikurangkan dengan menggunakan Medan Daya Molekul Merck (MMFF94) sehingga punca min kuasa dua (rms) kecerunan tenaga kurang daripada $0.005 \mathrm{kcal} \mathrm{mol}^{-1} \AA^{-1}$.

Model protein pula dibina berdasarkan struktur kristal domain DENV NS5 RdRp yang diambil daripada Bank Data Protein (PDB) (Noble et al. 2013) (kod PDB: 3VWS). Molekul air dalam struktur kristal tersebut dibuang. Atom hidrogen ditambah dan cas semua atom keseluruhan protein diberi dengan menggunakan potensi CHARMm.

Tapak aktif domain RdRp dianalisis dengan menggunakan program Accelrys Discovery Studio 3.1 untuk mengenal pasti dan menciri permukaan poket protein yang boleh dicapai. Perencat asal pada protein kod 3vws iaitu struktur dimer NITD 107-1 dan NITD 107-2 digunakan dalam analisis ini (Rajah 1). Program Accelrys Discovery Studio 3.1 digunakan untuk simulasi dok molekul. Tapak pengikat ligan ditakrif sebagai koleksi asid amino yang mengelilingi perencat asal dalam sfera radius $10 \AA$ A, Lys401, Thr605, Asn405 dan Thr413 (Noble et al. 2013).

\section{KEPUTUSAN DAN PERBINCANGAN}

Pada awalnya, dok molekul ke atas perencat asal protein 3Vws iaitu ligan NITD 107 yang wujud sebagai dimer NITD 107-1 dan NITD 107-2 dilakukan untuk menentukan tapak pengikat pada protein berkenaan. Rajah 2(a) dan 2(b) menunjukkan poket pengikat yang dikenal pasti. Domain pemangkin RdRp mengandungi sisa asid amino Lys401, Thr605, Asp492 dan Tyr606 bagi NITD 107-1 dan Asn405, Lys401, Arg792 dan Asn492 bagi NITD 107-2. Interaksi ligan dan sisa asid amino Lys401 dan Thr605 bagi NITD 107-1 dan Asn405 bagi NITD 107-2 adalah sama seperti yang dilaporkan dalam kajian lepas (Noble et al. 2013) tetapi tiada interaksi dilihat antara Thr413 bagi NITD 107-2 seperti yang dilaporkan.
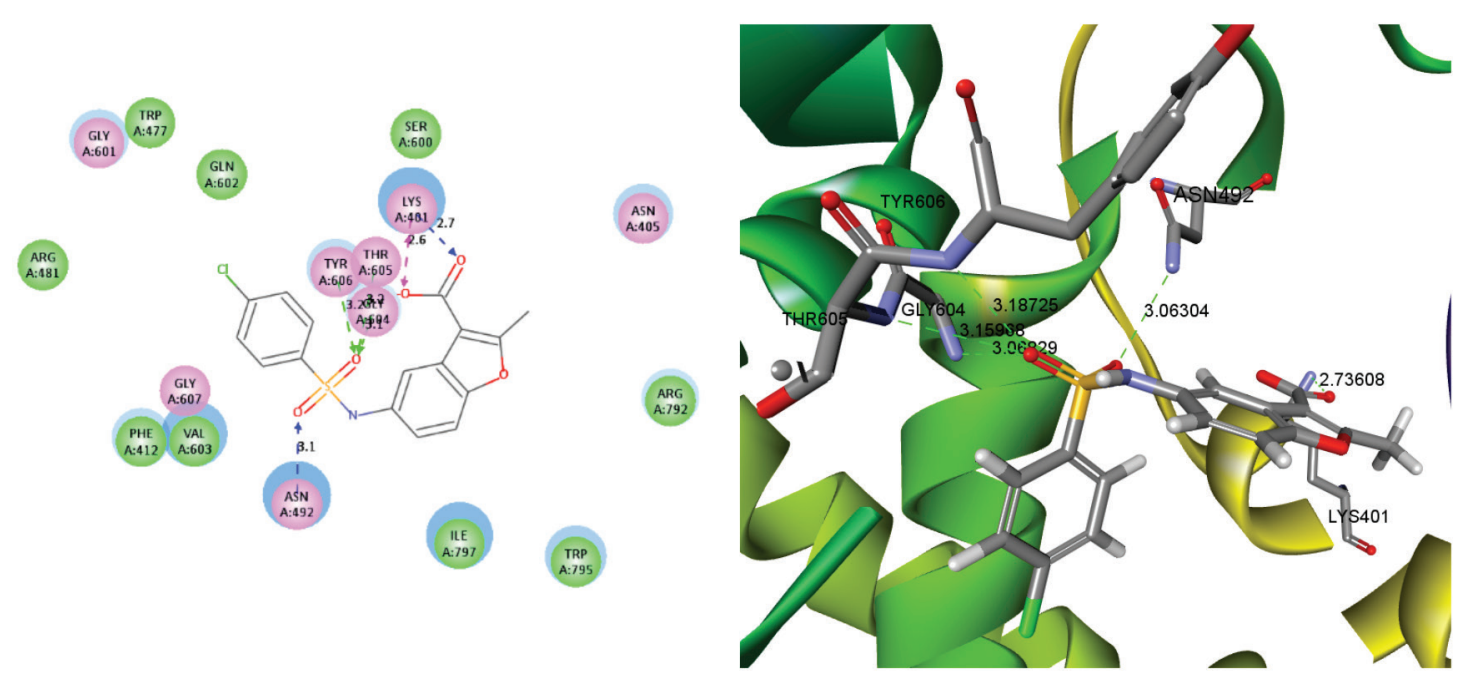

RAJAH 2(a). Gambar rajah 2D dan 3D bagi interaksi NITD107-1 dengan DENV berkod (3VWS)
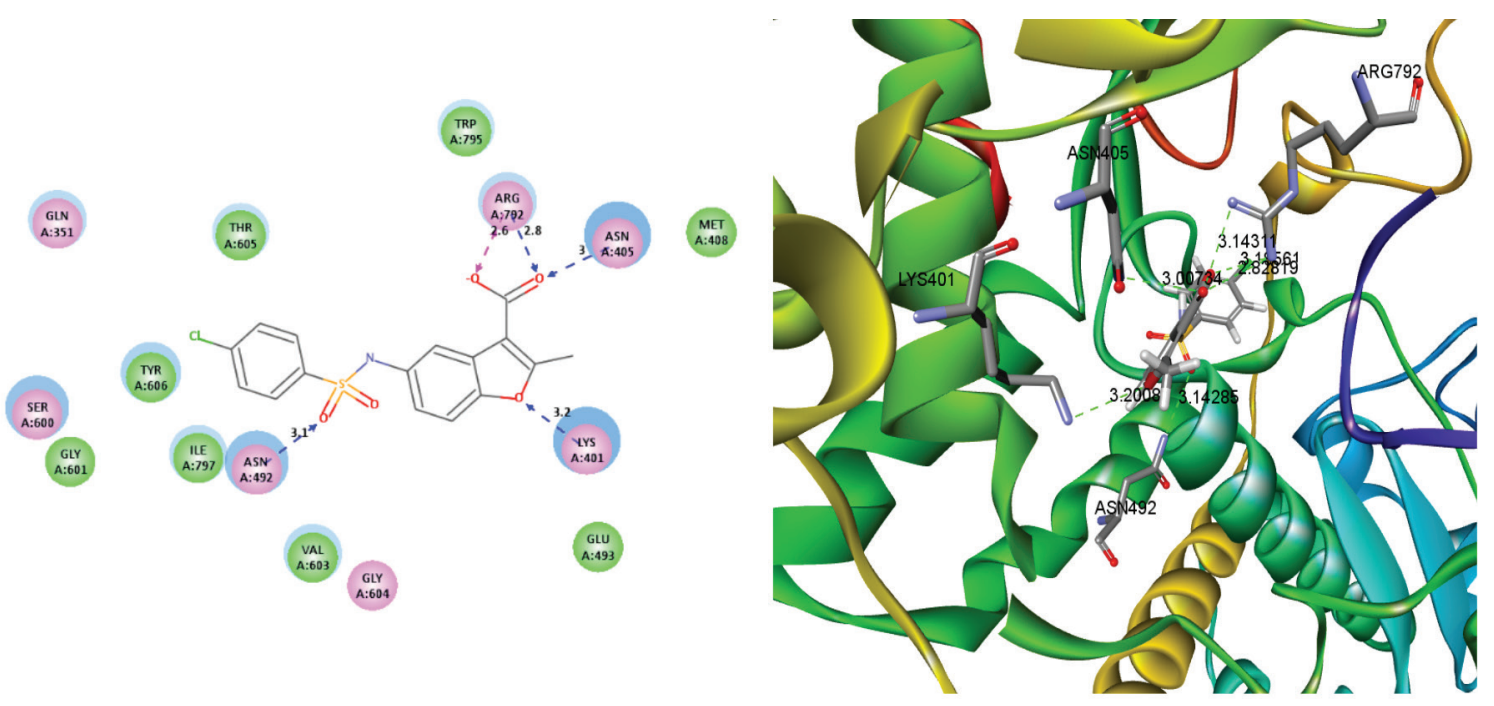

RAJAH 2(b). Gambar rajah 2D dan 3D bagi interaksi NITD107-2 dengan DENV berkod (3VWS) 
Setelah tapak pengikat dikenal pasti, kesemua 18 analog nukleosida komersial yang mempunyai mekanisme tindakan sebagai perencat enzim polimerase DNA (Jordheim et al. 2013) didok ke dalam domain pemangkin RdRp dalam bentuk sedia ada dan juga dalam bentuk trifosfat. Kajian ke atas ligan dalam bentuk trifosfat dilakukan bertujuan untuk mengetahui jenis dan bilangan interaksi yang terhasil antara ligan dan tapak aktif RdRp. Analog nukleosida juga hanya aktif dalam bentuk trifosfat kerana dalam bentuk ini analog nukleosida menyerupai substrat semula jadi RdRp (Öberg 2006). Kesemua analog nukleosida tersebut mempunyai struktur kimia yang berbeza daripada ligan NITD 107. Walau bagaimanapun, kesemua analog tersebut berinteraksi dengan sekurangkurangnya satu daripada sisa asid amino yang dinyatakan.

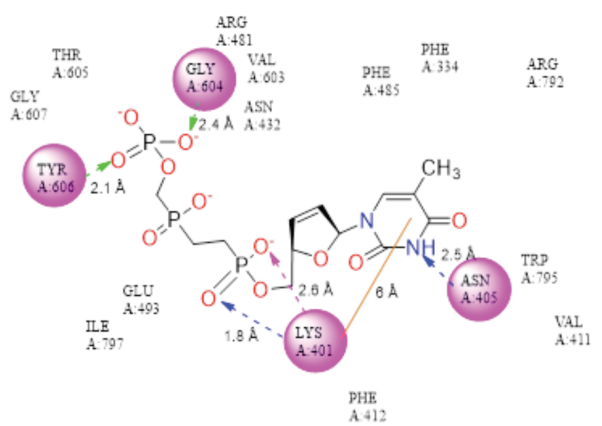

Stavudina trifosfat

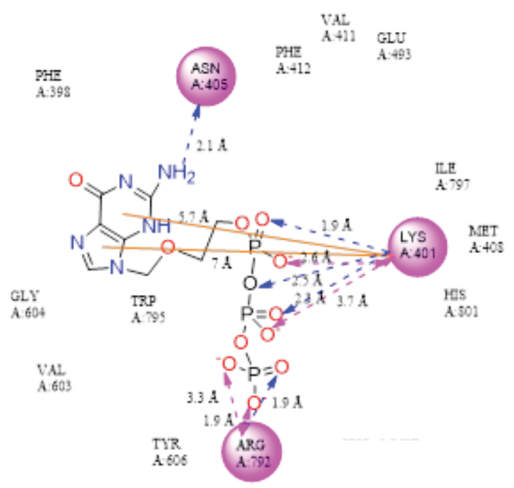

Asiklovir trifosfat
Secara keseluruhan, didapati bahawa analog dalam bentuk trifosfat mempunyai interaksi yang lebih dengan sisa asid amino berbanding analog dalam bentuk sedia ada. Interaksi utama yang dilihat antara ligan dan tapak aktif enzim adalah ikatan hidrogen, interaksi aromatik- $\pi$ dan interaksi cas. Hampir kesemua analog dalam bentuk trifosfat berinteraksi dengan Asn492. Interaksi antara kumpulan fosfat dan Asn492 ada dilaporkan dalam kajian terdahulu (Chapman \& Rossmann 1995). Interaksi ini tidak dilihat pada analog dalam bentuk sedia ada. Kajian ini juga menunjukkan bahawa analog stavudina, tenofovir, asiklovir, valgansiklovir dan adefovir dipivoxil dalam bentuk trifosfat mempunyai interaksi paling banyak dengan asid amino penting enzim RdRp (Rajah 3). Dapat dilihat bahawa bes pirimidina dan purina pada

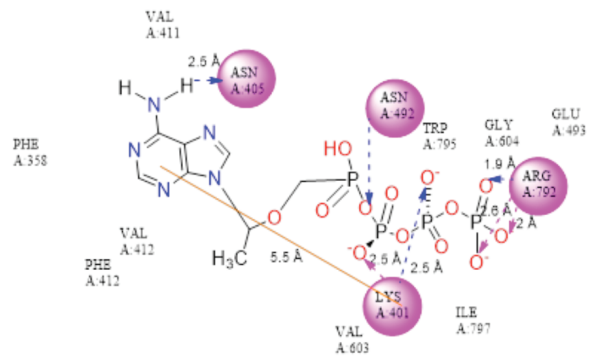

Tenofovir trifosfat

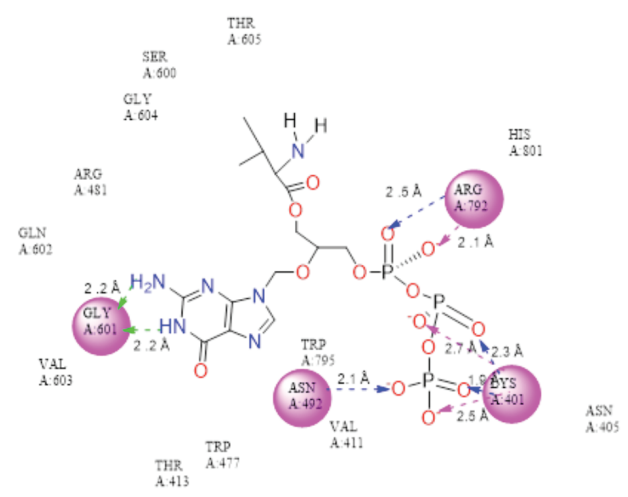

Valgansiklovir trifosfat

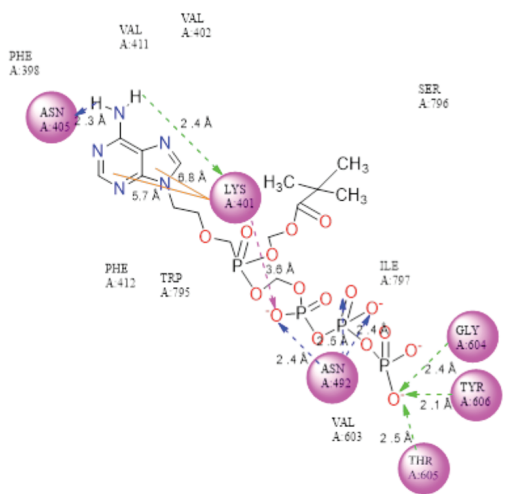

Adenofovir dipivoxil trifosfat

RAJAH 3. Interaksi di antara analog nukleosida dan sisa asid amino di tapak pengikat ligan 
analog nukleosida tersebut membentuk ikatan hidrogen dengan Asn405 dan Lys401. Interaksi aromatic- $\pi$ dengan Lys401 juga dapat dilihat. Walau bagaimanapun, interaksi ini tidak ditunjukkan oleh valgansiklovir dalam bentuk trifosfat walaupun dalam bentuk normal interaksi ini kelihatan. Ini mungkin disebabkan dalam bentuk trifosfat, konformasi analog tersebut berubah dan sisa asid amino Asn405 dan Lys401 sukar untuk dicapai. Interaksi yang dilihat pada bahagian bes valgasinklovir trifosfat adalah ikatan hidrogen dengan Gly601. Secara keseluruhan, kumpulan trifosfat analog nukleosida menunjukkan interaksi yang lebih banyak dengan sisa asid amino berbanding dengan bahagian bes. Interaksi yang dapat dilihat adalah ikatan hidrogen dan interaksi cas dengan Lys401, Thr605 dan Asn405 oleh kumpulan trifosfat.

Daripada mod interaksi yang terhasil di antara ligan dan tapak aktif enzim, farmakofor perencat dapat dijangka. Ia terdiri daripada gelang heterosiklik yang mengandungi atom nitrogen dan kumpulan fosfat yang dapat membuat ikatan hidrogen dan interaksi cas dengan sisa asid amino pada tapak aktif enzim. Penemuan ini selari dengan maklumat yang diperoleh daripada interaksi ligan asal NITD 107 dengan tapak aktif enzim dengan interaksi utama yang dilihat adalah melalui ikatan hidrogen (Noble et al. 2013). Melihat kepada keputusan kajian ini, adalah wajar untuk mereka bentuk analog nukleosida dengan kehadiran kumpulan fosfat. Dengan adanya kumpulan fosfat, langkah fosforilasi analog nukleosida dapat dikurangkan (Öberg 2006) dan masalah kerintangan virus yang tidak mengeluarkan enzim kinase untuk memfosforilasi analog nukleosida (Galmarini et al. 2001). Walau bagaimanapun, kehadiran kumpulan fosfat mempunyai cabarannya yang tersendiri dan yang paling utama ialah masalah penyerapan ke dalam sistem sistemik jika diberi secara oral (Bobeck et al. 2010). Masalah ini dapat diatasi dengan mereka bentuk analog nukleosida sebagai prodrug (Bobeck et al. 2010).

\section{KESIMPULAN}

Tapak pengikat ligan yang terdiri daripada sisa asid amino penting, Asn492, Asn405, Lys401, Thr605 dan Gly601 telah dikenal pasti dengan menggunakan tapak aktif domain enzim DENV NS5 RdRp. Lima analog nukleosida iaitu stavudina, tenofovir, asiklovir, valgansiklovir dan adefovir dipivoxil didok dengan baik ke dalam tapak pengikat ligan dan berinteraksi dengan ikatan hidrogen, interaksi aromatic- $\pi$ dan interaksi cas. Farmakofor bagi perencat yang berpotensi untuk berinteraksi dengan tapak aktif enzim juga telah diketahui. Kajian ini memberi maklumat berguna mengenai interaksi di antara analog nukleosida dan tapak aktif enzim RdRp. Ini dapat membantu dalam reka-bentuk rasional perencat baharu terhadap sasaran dadah yang penting ini.

\section{PENGHARGAAN}

Kajian ini telah dibiaya oleh Kementerian Pengajian Tinggi Malaysia (nombor geran FRGS/1/2012/SKK02/UKM/02/3).

\section{RUJUKAN}

Adachi, T., Ago, H., Habuka, N., Okuda, K., Komatsu, M., Ikeda, S. \& Yatsunami, K. 2002. The essential role of C-terminal residues in regulating the activity of hepatitis $\mathrm{C}$ virus RNAdependent RNA polymerase. Biochimica Biophysica Acta 1601: 38-48.

Bobeck, D.R., Schinazi, R.F. \& Coats, S.J. 2010. Advances in nucleoside monophosphate prodrugs as anti-HCV agents. Antiviral Therapy 15: 935-950.

Bruenn, J.A. 2003. A structural and primary sequence comparison of the viral RNA-dependent RNA polymerase. Nucleic Acid Research 31: 1821-1829.

Cerruti, H. \& Casas-Mollano, J.A. 2006. On the origin and function of RNA-mediated silencing: From protists to man. Current Genetics 50: 81-99.

Chapman, M. \& Rossmann, M.G. 1995. Single-stranded DNAprotein interactions in canine parvovirus. Structure 3(2): 151-162.

Chen, Y.L., Zheng, Y., Lakshminarayana, S.B., Qing, M., Schul, W., Duraiswamy, J., Kondreddi, R.R., Goh, A., Xu, H.Y., Yip, A., Liu, B.P., Weaver, M., Dartois, V., Keller, T.H. \& Shi, P.Y. 2010. Inhibition of dengue virus by an ester prodrug of an adenosine analog. Antimicrobial Agents and Chemotherapy 54(8): 3255-3261.

De Clercq, E. \& Neyts, J. 2009. Antiviral agent acting as DNA or RNA chain terminators. Dlm. Antiviral Strategies: Handbook of Experimental Pharmacology, disunting oleh De Clercq, E. \& Neyts, J. SpringerVerlag Berlin Heidelberg, Belgium: Rega Institute for Medical Research. hlm. 54-79.

Galmarini, C.M., Mackey, J.R. \& Dumontet, C. 2001. Nucleoside analogues: Mechanisms of drug resistance and reversal strategies. Leukemia 15: 875-890.

Jordheim, L.P., Durantel, D., Zoulim, F. \& Dumontet, C. 2013. Advances in the development of nucleoside and nucleotide analogues for cancer and viral diseases. Nature Reviews (Drug Discovery) 12: 447-464.

Malet, H., Masse, N., Selisko, B., Romette, J.L., Alvarez, K., Guillemot, J.C., Tolou, H., Yap, T.L., Vasudevan, S., Lescar, J. \& Canard, B. 2008. The flavivirus polymerase as a target for drug discovery. Antiviral Research 80: 23-35.

Noble, C.G., Lim, S.P., Chen, Y.L., Liew, C.W., Yap, L., Lescar, J. \& Shi, P.Y. 2013. Conformational flexibility of the dengue virus RNA-Dependent RNA polymerase revealed by a complex with an inhibitor. Journal of Virology 87(9): 5921-5295.

Öberg, B. 2006. Rational design of polymerase inhibitors as antiviral drugs. Antiviral Research 71(2-3): 90-95.

Steitz, T.A. 1998. A mechanism for all polymerases. Nature 391: 231-232.

Tan, B.H., Fu, J., Sugrue, R.J., Yap, E.H., Chan, Y.C. \& Tan, Y.H. 1996. Recombinant dengue type 1 virus NS5 protein expressed in Escherichia coli exhibits RNA-dependent RNA polymerase activity. Virology 216: 317-325. 
Drugs \& Herbal Research Centre

Faculty of Pharmacy

Universiti Kebangsaan Malaysia

Jalan Raja Muda Abdul Aziz

50300 Kuala Lumpur, Wilayah Persekutuan

Malaysia
*Pengarang untuk surat-menyurat; email: malina@ukm.edu.my

Diserahkan: 8 Jun 2017

Diterima: 24 Oktober 2017 